\title{
Psychometric Properties of Turkish Version of Survey of Activities and Fear of Falling in the Elderly Among Patients with Parkinson's Disease
}

\author{
Parkinson Hastalığında Yaşlılarda Aktivite ve Düşme Korkusu Anketi Türkçe \\ Versiyonunun Psikometrik Özellikleri
}

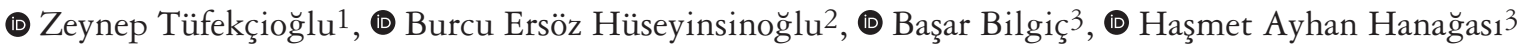 \\ ${ }^{1}$ Istanbul Aydin University Faculty of Medicine, Department of Neurology, Istanbul, Turkey \\ 2Istanbul University-Cerrahpasa, Faculty of Health Sciences, Department of Physiotherapy and Rehabilitation, Istanbul, Turkey \\ 3Istanbul University, Istanbul Faculty of Medicine, Department of Neurology, Division of Behavioral Neurology and Movement Disorders, \\ Istanbul, Turkey
}

\begin{abstract}
Objective: Fear of falling (FOF) is one of the important risk factors for falling, is higher in patients with Parkinson's disease (PD). The Survey of Activities and Fear of Falling in the Elderly (SAFFE) differs from other scales in terms of considering the accompanying activity limitation. The aim of the study was to show the psychometric properties of the Turkish version of SAFFE (SAFFE-T) in PD, and to correlate SAFFE FOF subscale scores with age, disease duration, and the Turkish version of Movement Disorder Society Unified Parkinson's Disease Rating Scale-III (MDS-UPDRS-TR-III) motor score.

Materials and Methods: A total of 93 patients with PD were evaluated. Seventy patients who met the inclusion criteria were included. Responders received a second survey after about 5 to 7 days. The internal consistency was examined by means of Cronbach's alpha. The construct validity was evaluated using the Falls Efficacy Scale International (FES-I) and with Spearman's test. The test-retest reliability was studied in terms of intraclass correlation coefficient (ICC 2.1 ), the standard error of measurement (SEM), and the minimal detectable difference $\left(\mathrm{MDC}_{95}\right)$. The correlation between SAFFE FOF subscale scores and age, duration of disease, and MDS-UPDRS-TR-III score was evaluated using Spearman's test.

Results: The mean age of the patients was 60.99 (range: 33-84), mean duration of the disease was 7.27 years (range: 1-22), and mean MDS-UPDRS-TR-III score was 28.40 (range: 6-69). The test had excellent internal consistency $(\alpha: 0.854)$ and test-retest reliability (ICC ${ }_{2.1}: 0.98 /$ SEM: $0.36 /$ MDC $_{95}: 1.00$ for activity levels, ICC $_{21}: 0.86 /$ SEM: $0.22 / \mathrm{MDC}_{05}: 0.61$ for FOF, ICC ${ }_{21}: 0.99 / \mathrm{SEM}: 0.36 / \mathrm{MDC}_{95}: 1.00$ for activity restriction subscales). All subscales were moderately correlated with the FES-I $\left(\mathrm{r}_{\mathrm{s}}=0.51, \mathrm{p}<0.001 ; \mathrm{r}_{\mathrm{s}}=0.59, \mathrm{p}<0.001 ; \mathrm{r}_{\mathrm{s}}=0.56, \mathrm{p}<0.001\right.$, respectively). The SAFFE-FOF subscale score was correlated with MDS-UPDRS-TR-III score $\left(r_{s}=0.31, p=0.009\right)$, but it was not correlated with age and duration of disease $\left(r_{s}=0.22, p=0.85 ; r_{s}=0.11, p=0.38\right.$, respectively).
\end{abstract}

Conclusion: The SAFFE-T, which has excellent internal consistency and reliability, appears to be an appropriate survey for measuring FOF in PD and correlates with disease severity.

Keywords: Activity restriction, fear of falling, psychometrics, reliability, validity, Parkinson's disease

$\ddot{O} \mathbf{z}$

Amaç: Düşme korkusu (DK), düşme için önemli risk faktörlerinden biridir. Sağlıklı kişilere oranla Parkinson hastalı̆̆ı (PH) olan bireylerde daha fazladır. Yaşlılarda Aktivite ve Düşme Korkusu Anketi (YADKA), DK'yi sorgularken eşlik eden aktivite kısıtlamasını da ele alarak diğer ölçeklerden farklılık gösterir. Çalışmamızın amacı, YADKA'nın Türkçe versiyonunun PH'de psikometrik özelliklerinin incelenmesi ve anketin DK skoru (DKS) ile yaş, hastalık süresi ve Hareket Bozuklukları Derneği Birleşik Parkinson Hastalığı Derecelendirme Ölçeği Türkçe versiyonu-kısım III (HBD-BPHDÖ-TR-III) motor skoru ile korelasyonunun incelenmesidir.

Gereç ve Yöntem: Çalışmaya dahil edilmek üzere 93 PH'li hasta değerlendirildi. Dahil edilme kriterlerine uyan 70 hasta çalışmaya alındı. Beş-yedi gün arayla anket tekrarlandı. İç tutarlılık Cronbach's $\alpha$ ile hesaplandı. Yapı geçerliliği, Uluslararası Düşme Etkinlik Skalası (UDES) ile YADKA arasında Spearman korelasyon testi ile değerlendirildi. Test-tekrar test güvenirliği, sınıf içi korelasyon (ICC ${ }_{2,1}$ ), ölçüm standart hatası (SEM) ve saptanabilir minimum değişiklik $\left(\mathrm{MDC}_{95}\right)$ ile belirlendi. Anket-DKS ile yaş, hastalık süresi ve HBD-BPHDÖ-TR-III skorunun korelasyonuna Spearman korelasyon testi ile bakıldı.

Bulgular: Hastaların ortalama yaşı 60,99 (aralık: 33-84), ortalama hastalık süresi 7,27 yıl (aralık: 1-22) ve ortalama HBD-BPHDÖ-TR-III skoru 28,40 (aralık: 6-69) idi. Anketin iç tutarlılı̆̆ çok yüksek bulundu ( $\alpha: 0,854)$. Alt skorların test-tekrar test güvenirliği yüksekti (aktivite düzeyi ICC ${ }_{2,1}: 0,98 /$ SEM: $_{0}$ 0,36/MDC ${ }_{95}:$

Address for Correspondence/Yazışma Adresi: Zeynep Tüfekçioğlu MD, Istanbul Aydin University Faculty of Medicine, Department of Neurology, Istanbul, Turkey Phone: +90 5304012844 E-mail: tufekcioglu.z@ gmail.com ORCID: orcid.org/0000-0001-6989-8611

Received/Gelis Tarihi 19.08.2020 Accepted/Kabul Tarihi: 21.12 .2020

${ }^{\circ}$ Copyright 2021 by Turkish Neurological Society

Turkish Journal of Neurology published by Galenos Publishing House. 


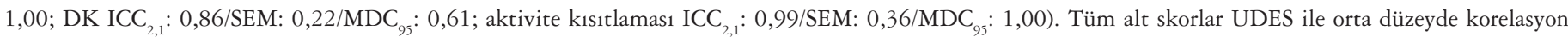

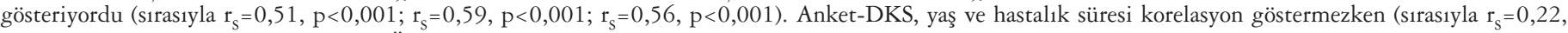
$\left.\mathrm{p}=0,85 ; \mathrm{r}_{\mathrm{s}}=0,11, \mathrm{p}=0,38\right)$ HBD-BPHDÖ-TR-III skoru ile korele idi $\left(\mathrm{r}_{\mathrm{s}}=0,31, \mathrm{p}=0,009\right)$.

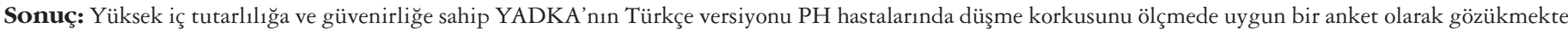
ve hastalık şiddeti ile korelasyon göstermektedir.

Anahtar Kelimeler: Aktivite kısıtlaması, düşme korkusu, psikometri, geçerlilik, güvenirlik, Parkinson hastalı̆̆1

\section{Introduction}

Falls are one of the most important causes of morbidity in patients with Parkinson's disease (PD) (1). Approximately 60\% of patients with PD fall at least once a year and falls recur in at least one-third of these patients (2,3). Falling in PD occurs as a result of a complex interaction of many factors that have yet to be explained (4). It is very important in terms of public health to reduce the risk of falling in PD because it causes injuries, fear of falling (FOF), decreased independence, decreased quality of life, lack of self-confidence, and increased health expenses. However, prevention approaches against falls are still not sufficient (4).

The FOF caused by falling causes the patient to decrease his/her sense of self-confidence, to move away from social life to prevent falling, and to choose a less active lifestyle, and together with these, it also causes an increase in the risk of falling $(5,6)$. This situation becomes a vicious cycle over time. Some $28-55 \%$ of the elderly living at home are afraid of falling, and this rate rises to $50-65 \%$ in those who have fallen before $(7,8)$. In patients with PD, this rate is much higher than in healthy controls and is important in predicting future falls $(9,10,11,12)$. Therefore, it is recommended to consider the FOF while evaluating balance in PD (10). Evaluating patients with PD in terms of FOF, recognizing risk factors early, and educating patients and the individuals they live with can reduce the incidence of falls. For this reason, it is very important to detect the FOF and activity limitation caused by this.

There are different scales to evaluate the FOF. One of the most frequently used methods in evaluating the FOF in large-scale studies and prevalence studies is posing a single dichotomous question (13). However, with this approach, the severity of the FOF and the FOF in different activities cannot be evaluated. The first test developed for these deficiencies is the "Falls Efficacy Scale (FES)" (14). This scale examines the confidence level of ten different activities of daily living (ADL) to complete without falling. Various modifications of this scale were developed subsequently and validity-reliability studies were conducted. Activitiesspecific Balance Confidence Scale (ABC), which is a similar scale, measures balance confidence. This scale evaluates the confidence in performing ADLs, which are more difficult and done outside the home, without losing balance or becoming indecisive (15). However, these tests or scales only evaluate the risk of falling. They cannot give information about the activity level, FOF, activity limitation, and why the activity is not performed. To eliminate these limitations, the Survey of Activities and Fear of Falling in the Elderly (SAFFE) was developed by Lachman et al. (16). This scale consists of 11 items that include ADL, mobility, and social activities. It focuses on the FOF and helps identify the negative effects of the FOF. The validity-reliability study of the Turkish version of SAFFE was recently performed (17).

Reliability and validity tests should be examined specifically for each patient type because the prevalence of FOF is higher in patients with PD than in healthy controls. The structure validity and test-retest reliability of the Turkish version of the test in PD have not been performed this far. The aim of this study was to determine the psychometric properties of SAFFE in PD and to look at the correlation of the questionnaire with the FOF score with age, disease duration, and the third part (motor) score of the Turkish version of the Movement Disorder Society-Unified Parkinson's Disease Rating Scale-III (MDS-UPDRS-TR-III).

\section{Materials and Methods}

\section{Patients}

Out of 93 patients who were consecutively admitted to the Movement Disorders Outpatient Clinic of Istanbul University, Istanbul Faculty of Medicine, Department of Neurology, and diagnosed as having idiopathic PD according to the criteria of the United Kingdom Brain Bank and continued medical treatment, 70 patients who met the inclusion criteria were included in the study (18). While calculating the sample size, the number of items in the survey was taken into account. Considering the sample-item ratio (2-20 patients for each item) recommended for the studies, it was predicted to include 70 patients for this 11-item survey (19).

The research plan was approved scientifically and ethically by the Non-Interventional Clinical Research Ethics Committee of Istanbul Aydin University (decision no: 2020/279, date: 30.06.2020). All patients included in the study were informed about the purpose, duration, and evaluations to be made. All patients were included in the study after they signed the "Informed Consent Form" approved by the Non-Interventional Clinical Research Ethics Committee of Istanbul Aydin University and the study was conducted in accordance with the Declaration of Helsinki.

\section{Inclusion and Exclusion Criteria}

To avoid difficulties in terms of cooperation in the tests performed in our study, it was planned to recruit patients without a known history of dementia, advanced vision and hearing loss, who had at least five years of education, could be mobilized alone without an assistive device, and did not have frequent freezing. The following inclusion and exclusion criteria were used.

\section{Inclusion criteria:}

- Being diagnosed as having idiopathic PD according to the United Kingdom Brain Bank criteria (18).

- Having stage I-III disease according to the Hoehn-Yahr classification.

- Having a score of 24 or above in the standardized minimental test (SMMT) $(20,21)$.

- Having a score between $0-3(\leq 3)$ in item 3 of freezing of gait questionnaire $(22,23)$.

- Being able to walk independently on flat ground without assistive devices. 


\section{Exclusion criteria:}

- Having any neurologic disease other than PD.

- Having any cardiac or orthopedic disorder that could prevent walking.

- Having severe hearing or visual problems.

- Having education of fewer than five years.

\section{Scales Used}

All evaluations in the study were made during the "on" period of the patients. Hoehn-Yahr staging was used to determine disease severity, and early and middle-stage patients were included in the study. The Turkish version of the third item of the freezing of gait questionnaire was used because it was a good method for evaluating the frequency of freezing that occurred during walking. In this test, each answer to questions is scored between " 0 " and " 4 " and the worst condition is scored as " 4 ". The third question is about the frequency of freezing. Patients who score 4 points from this question, that is, those with constant freezing, were not included in the study. The SMMT was performed to evaluate cognitive functions. In this test, which has a highest score of 30 , patients with an SMMT score of 24 or above were included in the study.

To determine the severity of the motor symptoms of the patients who met the inclusion criteria, part 3 (motor) of the MDS-UPDRS-TR-III was used. The scale consists of 18 items (24). Some items also consist of two subitems. Each subitem is scored between 0 and 4 , from mild to severe, depending on the severity of the examination finding. The score range of the third part is between $0-132$. The higher the total score in the test, the higher the severity of the disease.

The FES International (FES-I) was used in the validity study. There are 16 items in the scale (25). Each item evaluates a different activity, and each item evaluates the concern for the possibility of falling while performing this activity. If the patient's answer is "no concern", then it is scored 1 point; "somewhat concerned" 2 points; "fairly concerned" 3 points and "very concerned" 4 points. The total score of the test is the sum of the scores obtained from each item. The score range is between 16-64.

The SAFFE is an 11-point survey completed by the person. In each section, data on activity level, FOF, and activity limitation are obtained. These sections are scored as follows $(16,17)$.

A. Activity level: It is scored according to the number of activities performed among 11 activities. A "no" answer and lack of any answer get 0 points, and a "yes" answer gets 1 point. Those " 1 point"s are added up. The range is $0-11$ points.

B. Fear of falling: A new encoding is done in a way that low scores indicate low level of fear: $0=\mathrm{I}$ don't worry at all, $4=\mathrm{I}$ worry a lot, in the new encoding; $4=0,3=1,2=2,1=3$. FOF score is calculated according to the average anxiety score of 11 activities or the number of activities performed (for example, the "yes" answers in part A). The range is between 0 and 3 points.

F. Activity limitation: It is the number of activities stated to be done less than before. The number of the answer "I do less than I used to do" to the question "Can you say you do ........ less compared to five years ago?" The range is between 0 and 11 points.

In the first evaluation, SAFFE was performed by the patient, under the supervision of a physiotherapist. All of the patients were included in the test-retest reliability study, and 5-7 days after the first evaluation, SAFFE was performed by the patient for the second time with the physiotherapist.

\section{Statistical Analysis}

The Statistical Package for the Social Sciences (SPSS) Version 22.0 (SPSS Inc., Chicago, IL, USA) package program was used for the statistical analysis of the study data. The "KolmogorovSmirnov test" was performed to determine the conformity of the data to normal distribution. In the statistical analysis of the study, variables were defined with mean, standard deviation (SD), and minimum and maximum values. Reliability studies were performed using the test-retest method. Accordingly, the internal consistency of the survey was calculated using Cronbach's $\alpha$. A value between 0.70-0.95 was considered sufficient (26). Testretest reliability was measured by intraclass correlation coefficient $\left(\mathrm{ICC}_{2.1}\right)$, standard error of measurement (SEM), and minimal detectable change $\left(\mathrm{MDC}_{95}\right)$. An ICC value of 0.75 or above was deemed appropriate for reliability (27). The SEM was calculated using the formula "SD. $\sqrt{ }\left(1-\mathrm{ICC}_{2.1}\right.$ ". The $\mathrm{MDC}_{95}$ was calculated using the formula "SEM.1.96. $\sqrt{2}$ ". The construct validity of the survey was assessed using Spearman's correlation test between the FES-I and SAFFE. A correlation coefficient above 0.5 was considered sufficient (26). The correlation analysis of the "FOF" score of SAFFE with age, disease duration, and the third part (motor) score of the MDS-UPDRS-TR was performed using the Spearman correlation test. In all analyses, a $\mathrm{p}<0.05$ (two-sided) was considered statistically significant.

\section{Results}

Ninety-three patients with PD were evaluated. Of these, 23 were excluded; two for knee problems, three for cognitive impairment, four for reluctance for inclusion, 13 for low education level, and one for not being available for retesting. A total of 70 patients with PD (24 women, 46 men) were included in the study. The mean age was 60.99 (range: 33-84) years, the mean disease duration was 7.27 (range: 1-22) years, the mean motor score of the MDS-UPDRS-TR-III part was 28.40 (range: 6-69), and mean FOF score of SAFFE was 0.36 (range: $0-2.18$ ). The demographic and clinical characteristics of the patients are shown in Table 1.

\section{Internal Consistency}

The internal consistency of the survey in the first evaluation was found to be very high ( $\alpha$ : 0.854). The distribution and internal consistency of the first evaluation of the survey's FOF sub-score are shown in Table 2. Item total correlation was between 0.725 0.296. When a single item was deleted, the Cronbach's $\alpha$ value was not much different from the overall $\alpha$ value (0.862-0.825), indicating that the scale was homogeneous.

\section{Reliability}

The average and standard errors of the first and second evaluation of the test's sub-scores are shown in Table 3. Testretest reliability results of the sub-units of the test were as follows: Activity level $\mathrm{ICC}_{2.1}: 0.98 / \mathrm{SEM}: 0.36 / \mathrm{MDC}_{95}: 1.00$; FOF: $\mathrm{ICC}_{2.1}$ : 0.86/SEM: $0.22 /$ MDC $_{95}: 0.61$; and the activity limitation ICC $_{2.1}$ : 0.99/SEM: 0.36/ MDC $_{95}: 1.00$ (Table 3). According to these values, the test-retest reliability of the sub-scores was high. 


\section{Structure Validity}

All sub-scores were moderately correlated with FES-I (activity level: $\mathrm{r}_{\mathrm{s}}=0.56, \mathrm{p}<0.001 ; \mathrm{FOF}: \mathrm{r}_{\mathrm{s}}=0.59, \mathrm{p}<0.001$; and activity limitation: $\left.r_{s}=0.56, p<0.001\right)($ Table 4).
The SAFFE's FOF score did not correlate with the age and duration of illness in the elderly. It was observed that the FOF score of SAFFE was associated with the third part (motor) score of MDS-UPDRS-TR $\left(\mathrm{r}_{\mathrm{s}}=0.31, \mathrm{p}=0.009\right)$ (Table 5).

Table 1. Demographic and clinical characteristics of the patients

Total sample: 70 patients

Sex (female/male), n (\%)

Mean age \pm SD (range), years

Mean education level \pm SD (range), years

Median H\&Y (range), score

Average MMSE \pm SD (range), score

Mean MDS-UPDRS-TR-III \pm SD (range), score

Mean FES-I \pm SD (range), score

Mean SEFFA-FEF \pm SD (range), score
Mean duration of illness \pm SD (range), years

$24(34.4 \%) / 46(65.7 \%)$
$60.99 \pm 11.31(33-84)$
$8.61 \pm 4.24(4-20)$
$7.27 \pm 4.08(1-22)$
$2(1-3)$
$28.77 \pm 1.24(25-30)$
$28.40 \pm 13.43(6-69)$
$21.44 \pm 9.03(19-59)$
$0.36 \pm 0.58(0-2.18)$

SD: Standard deviation, H\&Y: Hoehn-Yahr score, MMSE: Mini-mental state examination, MDS-UPDRS-TR-III: Movement Disorders Society-Unified Parkinson Disease Rating Scale Turkish version part III, FES-I: International Fall Efficiency Scale, SAFFE-FEF: Survey of Activities and Fear of Falling in the Elderly-Fear of Falling

Table 2. The Survey of Activities and Fear of Falling in the Elderly-Fear of Falling score distribution and its internal consistency

\begin{tabular}{|c|c|c|c|}
\hline & $\begin{array}{l}\text { Mean score when an } \\
\text { item was deleted }\end{array}$ & Score-total correlation & $\begin{array}{l}\text { Cronbach's alpha } \\
\text { when a score was } \\
\text { deleted }\end{array}$ \\
\hline 1. Do you go to the market? & 2.74 & 0.540 & 0.843 \\
\hline 2. Can you prepare simple meals (snacks)? & 2.83 & 0.515 & 0.846 \\
\hline 3. Can you have a bath alone? & 2.36 & 0.525 & 0.850 \\
\hline 4. Can you get out of bed alone? & 2.67 & 0.598 & 0.837 \\
\hline 5. Do you walk for exercise? & 2.74 & 0.553 & 0.842 \\
\hline 6. Do you go out when the ground is slippery? & 2.53 & 0.296 & 0.862 \\
\hline 7. Can you visit a friend or relative? & 2.80 & 0.631 & 0.841 \\
\hline 8. Can you reach for something above your head level? & 2.54 & 0.724 & 0.825 \\
\hline 9. Do you go to crowded places? & 2.71 & 0.595 & 0.838 \\
\hline 10. Can you walk more than 500 meters outside? & 2.66 & 0.725 & 0.826 \\
\hline 11. Can you bending over to get something? & 2.56 & 0.517 & 0.844 \\
\hline
\end{tabular}


Table 4. Correlation of the sub-scores of the Survey of Activities and Fear of Falling in the Elderly with International Fall Efficiency Scale

\begin{tabular}{llll|} 
FES-I & SAFFE activity level & SAFFE fear of falling & SAFFE activity restriction \\
Spearman Correlation $(\mathrm{rS})$ & -0.51 & 0.59 & 0.56 \\
$\mathrm{p}$ & $<0.001$ & $<0.001$ & $<0.001$ \\
$\mathrm{~N}$ & 70 & 70 & 70 \\
FES-I: International Fall Efficiency Scale, SAFFE: Survey of Activities and Fear of Falling in the Elderly, N: Number & \\
\hline
\end{tabular}

Table 5. The correlation of the Survey of Activities and Fear of Falling in the Elderly-Fear of Falling score with age, disease duration, Movement Disorders Society Unified Parkinson Disease Rating Scale Turkish version part-III score

\begin{tabular}{llll} 
SAFFE-FEF score & Age & Disease duration & MDS-UPDRS-TR-III \\
Spearman Correlation (rS) & 0.22 & 0.11 & 0.31 \\
p & 0.85 & 0.38 & $0.009^{*}$ \\
N & 70 & 70 & 70 \\
*: p<0.05, SAFFE-FEF: Survey of Activities and Fear of Falling in the Elderly-Fear of Falling score, MDS-UPDRS-TR-III: Movement Disorders Society-Unified Parkinson \\
\hline
\end{tabular}

\section{Discussion}

FOF is an important problem that is frequently seen in patients with PD and counted among the causes of recurrent falls. Studies have shown a high correlation between decreased mobility and FOF in patients with PD and limitation in activities was found in $70 \%$ of patients due to $\operatorname{FOF}(28,29)$. For these reasons, evaluating the FOF in patients with PD and determining individually which activities trigger this fear more will be guiding for the rehabilitation programs of the patients (30). There are different scales in the literature that evaluate the FOF. The most important feature that distinguishes SAFFE from these scales is that it questions the level of activity and why the activity cannot be performed, as well as the FOF felt during various daily life activities. Therefore, the use of SAFFE in PD is important in terms of providing information about both the presence of FOF and the activity limitation it causes. Recently, the validity and reliability study of the Turkish version of SAFFE in healthy elderly people was conducted and the survey was shown to be valid and reliable (17).

In the present study, the psychometric properties of the Turkish version of SAFFE were studied in patients with PD and the correlation of the FOF score with age, disease duration, and disease severity was examined. According to the results of the study, the Turkish version of SAFFE was found to be acceptable ( $\alpha$ : $0.96)$ and reliable $(\mathrm{p}=0.75, \mathrm{p}<0.001)$ for determining the FOF in patients with PD. This rate was similar to the internal consistency rate $(\alpha: 0.94)$ shown by SAFFE applied in this patient group and adapted to the Swedish language $(31,32)$.

ICC values, which were examined for test-retest reliability assessment for activity level, FOF, and activity limitation, which were subitems of the survey, were found as 0.98, 0.86, and 0.99 , respectively. In this patient group, the ICC values for FOF questioning were slightly lower compared with the ICC values (ICC: 0.99, 0.94, and 0.94, respectively) in the psychometric study conducted with the Persian version of the survey (33). In the study of the survey, which was adapted to the Swedish language and performed in this patient group, the ICC value for FOF was 0.85
(0.78-0.90) and was similar (32). In that study, the 17-question version of SAFFE was used, and the scale was only translated into Swedish without going through the cultural adaptation stages.

When the validity results of our study were examined, it was observed that there was a high correlation with the FES-I $(\mathrm{rS}=0.59$, $\mathrm{p}<0.001)$. In the validity analysis of the Turkish version of SAFFE, it was found that the survey showed a high level of correlation with FES-I $\left(r_{s}=0.75, p<0.001\right)(17)$. Zarei et al. (33) used the ABC to evaluate the structural validity of the Persian SAFFE in this patient group and found a very high level of correlation $\left(r_{s}=-0.87\right.$, $\mathrm{p}<0.001)$. It was thought that the high correlation level in this study compared with our study might be due to differences in the content of the questions in the ABC scale and scoring in the form of giving points over a percentage rather than choosing one of the four answers as in FES-I.

While the survey's FOF score did not correlate with age and disease duration, it correlated with the third part (motor) score of the MDS-UPDRS-TR, which indicated that patients with more severe motor symptoms had a greater FOF. Similar to these findings, it was found in another study that patients with PD with more severe motor findings showed more movement avoidance behavior due to the FOF, and that it was not related to the duration of the disease (29).

\section{Study Limitations}

The most important limitation of our study was that it analyzed the psychometric properties of the test on a limited population by including early-middle-stage patients who did not have dementia, did not have advanced freezing, and could mobilize alone. Studying the psychometric properties of SAFFE in patients with PD who can mobilize with assistance in future studies may provide a valid and reliable scale for these patients, who are more frequently directed to rehabilitation attempts. Also, determining the FOF in patients with PD and the activities limited for this reason can be a guide in structuring rehabilitation programs accordingly. 


\section{Conclusion}

As a result, the Turkish version of SAFFE is a valid and reliable survey that can be used to evaluate the FOF in patients with PD. The FOF score of the survey correlates with the severity of the motor symptoms of PD. With this study, the Turkish version of SAFFE has become the first survey adapted to Turkish to evaluate the causes of activity limitation along with the FOF, in which psychometric properties specific to PD were investigated.

\section{Ethics}

Ethics Committee Approval: The research plan was approved scientifically and ethically by the Non-Interventional Clinical Research Ethics Committee of Istanbul Aydin University (decision no: 2020/279, date: 30.06.2020).

Informed Consent: All patients were included in the study after they signed the "Informed Consent Form" approved by the Non-Interventional Clinical Research Ethics Committee of Istanbul Aydin University and the study was conducted in accordance with the Declaration of Helsinki.

Peer-review: Internally peer-reviewed.

\section{Authorship Contributions}

Concept: Z.T., B.E.H., Design: Z.T., B.E.H., Data Collection or Processing: Z.T., B.E.H., B.B., H.A.H., Analysis or Interpretation: Z.T., B.E.H., B.B., H.A.H., Literature Search: Z.T., B.E.H., Writing: Z.T., B.E.H., H.A.H.

Conflict of Interest: No conflict of interest was declared by the authors.

Financial Disclosure: The authors declared that this study received no financial support.

\section{References}

1. Wood BH, Bilclough JA, Bowron A, Walker RW. Incidence and prediction of falls in Parkinson's disease: a prospective multidisciplinary study. J Neurol Neurosurg Psychiatry 2002;72:721-725.

2. Pickering RM, Grimbergen YA, Rigney U, et al. A meta-analysis of six prospective studies of falling in Parkinson's disease. Mov Disord 2007;22:1892-1900

3. Balash Y, Peretz C, Leibovich G, et al. Falls in outpatients with Parkinson's disease: frequency, impact and identifying factors. J Neurol 2005;252:13101315.

4. Fasano A, Plotnik M, Bove F, Berardelli A. The neurobiology of falls. Neurol Sci 2012;33:1215-1223.

5. Suzuki M, Ohyama N, Yamada K, Kanamori M. The relationship between fear of falling, activities of daily living and quality of life among elderly individuals. Nurs Health Sci 2002;4:155-161.

6. Robitaille Y, Laforest S, Fournier M, et al. Moving forward in fall prevention: an intervention to improve balance among older adults in real-world settings. Am J Public Health 2005;95:2049-2056.

7. Uz Tunçay S, Özdinçler AR, Erdinçler DS. The effect of risk factors for falls on activities of daily living and quality of life in geriatric patients. Turkish Journal of Geriatrics 2011;14:245-252.

8. Cumming RG, Salkeld G, Thomas M, Szonyi G. Prospective study of the impact of fear of falling on activities of daily living, SF-36 scores, and nursing home admission. J Gerontol A Biol Sci Med Sci 2000;55:M299-305.

9. Bloem BR, Grimbergen YA, Cramer M, Willemsen M, Zwinderman AH. Prospective assessment of falls in Parkinson's disease. J Neurol 2001;248:950-958.

10. Adkin AL, Frank JS, Jog MS. Fear of falling and postural control in Parkinson's disease. Mov Disord 2003;18:496-502.

11. Mak MK, Pang MY. Balance self-efficacy determines walking capacity in people with Parkinson's disease. Mov Disord 2008;23:1936-1939.
12. Mak MK, Pang MY. Fear of falling is independently associated with recurrent falls in patients with Parkinson's disease: a 1-year prospective study. J Neurol 2009;256:1689-1695.

13. Kempen GI, Todd CJ, Van Haastregt JC, et al. Cross-cultural validation of the Falls Efficacy Scale International (FES-I) in older people: results from Germany, the Netherlands and the UK were satisfactory. Disabil Rehabil 2007;29:155-162.

14. Tinetti ME, Richman D, Powell L. Falls efficacy as a measure of fear of falling. J Gerontol 1990;45:239-243.

15. Powell LE, Myers AM. The Activities-specific Balance Confidence (ABC) Scale. J Gerontol A Biol Sci Med Sci 1995;50A:M28-34.

16. Lachman ME, Howland J, Tennstedt S, et al. Fear of falling and activity restriction: the survey of activities and fear of falling in the elderly (SAFE). J Gerontol B Psychol Sci Soc Sci 1998;53:P43-50.

17. Ersoz Huseyinsinoglu B, Tufekcioglu Z, Birinci T, Demirdag F. The Reliability and Validity of the Turkish Version of the Survey of Activities and Fear of Falling in the Elderly. J Geriatr Phys Ther 2020 Feb 10. doi: 10.1519/JPT.0000000000000260. Epub ahead of print.

18. Hughes AJ, Daniel SE, Kilford L, Lees AJ. Accuracy of clinical diagnosis of idiopathic Parkinson's disease: a clinico-pathological study of 100 cases. J Neurol Neurosurg Psychiatry 1992;55:181-184.

19. Anthoine E, Moret L, Regnault A, Sébille V, Hardouin JB. Sample size used to validate a scale: a review of publications on newly-developed patient reported outcomes measures. Health Qual Life Outcomes 2014;12:176.

20. Güngen C, Ertan T, Eker E, Yaşar R, Engin F. Standardize Mini Mental Testinin Türk toplumunda hafif demans tanısında geçerlik ve güvenilirliği. Türk Psikiyatri Dergisi 2002;13:273-281.

21. Folstein MF, Folstein SE, McHugh PR. "Mini-mental state". A practical method for grading the cognitive state of patients for the clinician. J Psychiatr Res 1975;12:189-198.

22. Giladi N, Shabtai H, Simon ES, et al. Construction of freezing of gait questionnaire for patients with Parkinsonism. Parkinsonism Relat Disord 2000;6:165-170.

23. Acaröz Candan S, Çatıker A, Özcan TŞ. Psychometric properties of the Turkish version of the freezing of gait questionnaire for patients with Parkinson's disease. Neurol Sci Neurophysiol 2019;36:44-50.

24. Akbostanci MC, Bayram E, Yilmaz V, et al. Turkish Standardization of Movement Disorders Society Unified Parkinson's Disease Rating Scale and Unified Dyskinesia Rating Scale. Mov Disord Clin Pract 2017;5:54-59.

25. Ulus Y, Durmus D, Akyol Y, et al. Reliability and validity of the Turkish version of the Falls Efficacy Scale International (FES-I) in communitydwelling older persons. Arch Gerontol Geriatr 2012;54:429-433.

26. Terwee CB, Bot SD, de Boer MR, et al. Quality criteria were proposed for measurement properties of health status questionnaires. J Clin Epidemiol 2007;60:34-42.

27. Nunnally JC, Bernstein IH. Psychometric theory. 3rd ed. New York: McGraw-Hill, 1994.

28. Allen NE, Schwarzel AK, Canning CG. Recurrent falls in Parkinson's disease: a systematic review. Parkinsons Dis 2013;2013:906274.

29. Landers MR, Lopker M, Newman M, et al. A Cross-sectional analysis of the characteristics of individuals with Parkinson disease who avoid activities and participation due to fear of falling. J Neurol Phys Ther 2017;41:31-42.

30. Nilsson MH, Jonasson SB, Zijlstra GAR. Predictive factors of fall-related activity avoidance in people with parkinson disease-a longitudinal study with a 3-year follow-up. J Neurol Phys Ther 2020;44:188-194.

31. Nilsson MH, Drake AM, Hagell P. Assessment of fall-related self-efficacy and activity avoidance in people with Parkinson's disease. BMC Geriatr 2010;10:78.

32. Jonasson SB, Nilsson MH, Lexell J. Psychometric properties of four fear of falling rating scales in people with Parkinson's disease. BMC Geriatr 2014;14:66.

33. Zarei M, Lajevardi L, Zarei MA, Azad A, Mollazadeh E. Construct validity and test-retest reliability of survey of activities and fear of falling in the elderly among Iranian patients with Parkinson disease. Middle East J Rehabil Health 2016;3:e37442. 